\title{
MODELING BIOGEOMORPHOLOGICAL INTERACTIONS IN UNDERWATER NOURISHMENTS
}

\author{
Bas W. Borsje ${ }^{1,2}$ Maurits A. Kruijt ${ }^{2,3}$, Jebbe J. van der Werf ${ }^{2}$, Suzanne J.M.H. Hulscher ${ }^{1}$,
} Peter M.J. Herman ${ }^{4,5}$

\begin{abstract}
To prevent sandy coastlines from further erosion, nourishments are executed in which sand is usually put underwater at the foreshore. Waves and currents transport the sand on the beach and in this way stabilize the coastal profile. Little is known about the interactions of these so-called shoreface nourishments with the benthic populations inhabiting the coastal strip. Benthos is affected by the nourishments, but benthic populations could in turn affect the morphological evolution of the nourished coast. Monitoring has shown that the benthic community will mainly recovery after ca. 1 year. However, the impact of benthos on the sediment dynamics and hydrodynamics is unknown. In this paper we focus on tube building worms, which have a large abundance in the foreshore, live in patches of several square meters in diameter and protrude several centimeters from the sediment in the water column. Tube building worms are included in a numerical modeling tool (Delft3D), by explicitly accounting for the influence of cylindrical structures on drag and turbulence by an extra source term of friction force in the momentum equation and an extra source term of Total Kinetic Energy (TKE) and turbulent energy dissipation in the $\mathrm{k}-\varepsilon$ equations respectively. The model is validated against field and flume experiments and it shows a significant influence on flow velocities near the bed, bed shear stress and bed-load transport rates. Moreover, model results reveal that tube building worms are able to stabilize nourishments and slow down the migration of the outer breaker bar. Present model explorations indicate that future research should focus on the measurement of the patchy distribution of bio-engineers in the foreshore and their impact on the sediment dynamics and hydrodynamics. Such knowledge will enable process based modeling of the spatial and temporal variation in biological activity on the morphological development of the coastal profile and also it will lead to validation of the proposed model with field measurements.
\end{abstract}

Keywords: Biogeomorphology, Nourishments, Dutch coast, Bio-engineers, Building with Nature

\section{INTRODUCTION}

In The Netherlands, the shore is held in position by supplying sand on the beaches since 1979. Shoreface nourishments have become popular in the 1990s as an alternative to direct beach and duneface nourishments (Hamm et al., 2002; Hanson et al., 2002). In shoreface nourishment, sand is dumped subtidally between the outer breaker bars; natural forces are utilized to redistribute the sediment shoreward and hence the use of the beach is not hindered. This type of nourishment is less expensive compared to beach and duneface nourishments. Shoreface nourishments are an attractive option for coastal managers, but knowledge of the long-term effects of nourishments on the geomorphology and the ecosystem is limited (Borsje et al., 2009a). Several modeling and data analysis studies already addressed the long-term effect on geomorphology (e.g. Grunnet et al., 2004; Van Duin et al., 2004; Grunnet and Ruessink 2005; Van Leeuwen et al., 2007; Ojeda et al., 2008). However, many geomorphological processes occur in parallel with ecosystem processes at similar spatial and temporal scales, thus making the two mutually dependent (Renschler et al., 2007). Furthermore, the ecological aspects of sand nourishment have drawn additional attention in The Netherlands by the selection of beaches as protected sites (Natura 2000). A coupled understanding of how the two aspects of the environment influence each other, and how the processes feedback into each other will enable predictions of future states of beach ecosystems, and contribute to the development of effective and sustainable nourishment practices.

The aim of this paper is (1) to explore the interactions between biota and nourishments and (2) to model these biogeomorphological interactions in a process-based model. We will achieve these objectives by reviewing the effects of a shoreface nourishment both from a morphodynamic and ecological perspective and from the known impact of some key benthic species in the subtidal environment on the hydrodynamics and sediment dynamics (Section 2). We subsequently focus on methods to model such bio-geomorphological influences between a key benthic species and

\footnotetext{
${ }^{1}$ Faculty of Water Engineering \& Management, University of Twente, P.O. Box 217, 7500 AE, Enschede, The Netherlands.

${ }^{2}$ Deltares, Marine and Coastal systems, P.O. Box 177, 2600 MH, Delft, The Netherlands.

${ }^{3}$ Faculty of Civil Engineering and Geosciences, Delft University of Technology, P.O. Box 5, 2600 AA, Delft, The Netherlands.

${ }^{4}$ Centre for Estuarine and Marine Ecology, Netherlands Institute of Ecology (NIOO-KNAW), P.O. Box 140, 4400 AC, Yerseke, The Netherlands.

${ }^{5}$ Faculty of Environmental Sciences, Radboud University Nijmegen,P.O. Box 9102, 6500 HC, Nijmegen, The Netherlands.
} 
hydrodynamics plus sediment dynamics (Section 3) and show the results of the model (Section 4). Next the main findings of this paper are discussed (Section 5), and some general conclusions are drawn (Section 6). In the present paper we use the Dutch part of the North Sea as an example, as it has been relatively well described with respect to nourishments and organisms (details in the next Sections).

\section{INTERACTION BETWEEN BENTHOS AND NOURISHMENTS}

Nourishments are a 'soft engineering' approach, which Dutch coastal engineers adopt to fulfill the desired safety levels (Figure la for quantification). In this approach sand is put on the beach or on the shoreface for three reasons: to improve coastal stability, to fulfill coastal protection or to enhance recreation (De Ronde et al., 2003). The current policy (2000-2007) is to nourish yearly 12 $\mathrm{Mm}^{3}$ sand in the Dutch coastal system, of which about $60 \%$ by means of relatively large $\left(10^{6} \mathrm{~m}^{3}\right)$ shoreface nourishments and $40 \%$ by means of relatively small $\left(10^{5} \mathrm{~m}^{3}\right)$ beach nourishments. The largest part (49\%) of the $12 \mathrm{Mm}^{3}$ of nourished sand is put into the central Dutch coast (between Hoek van Holland and Den Helder). The Wadden and the Southwestern coastal system receive $28 \%$ and $23 \%$, respectively. The shoreface nourishments typically have a volume of $1-3 \mathrm{Mm}^{3}\left(400-600 \mathrm{~m}^{3} \mathrm{~m}^{-1}\right)$. After 2007, beach nourishments are almost fully replaced by shoreface nourishments (Baptist et al., 2009).

From an ecological perspective, the biodiversity at the Wadden Coast shows a clear difference compared to the biodiversity at the Central Dutch coast and the Southwestern Dutch coast (Figure 1b). The beach zone (depths between 1 and $7 \mathrm{~m}$; distance between 0 and $700 \mathrm{~m}$ from the lowwater line) at the Wadden Coast are characterized by fine sand $\left(\mathrm{d}_{50}<260 \mu \mathrm{m}\right)$ which is poor in carbonate content $(<2 \%)$ and easily penetrated by benthos. The sediment is poorly sorted, i.e. it contains a mixture of grains of different sizes. These beaches are relatively flat and high diversity and abundance are found. The beaches along the Central Dutch coast and Southwestern Dutch coast are steeper and consist of coarser $\left(\mathrm{d}_{50}>300 \mu \mathrm{m}\right)$ and better sorted sand. The carbonate content in the sediment of the beaches south of Egmond is higher than that of the Wadden Coast beaches $(>10 \%)$. Penetrating the sediment requires greater strength and the diversity and abundance are not as high as on the beaches of the Dutch Wadden Sea islands (Janssen and Mulder, 2005).
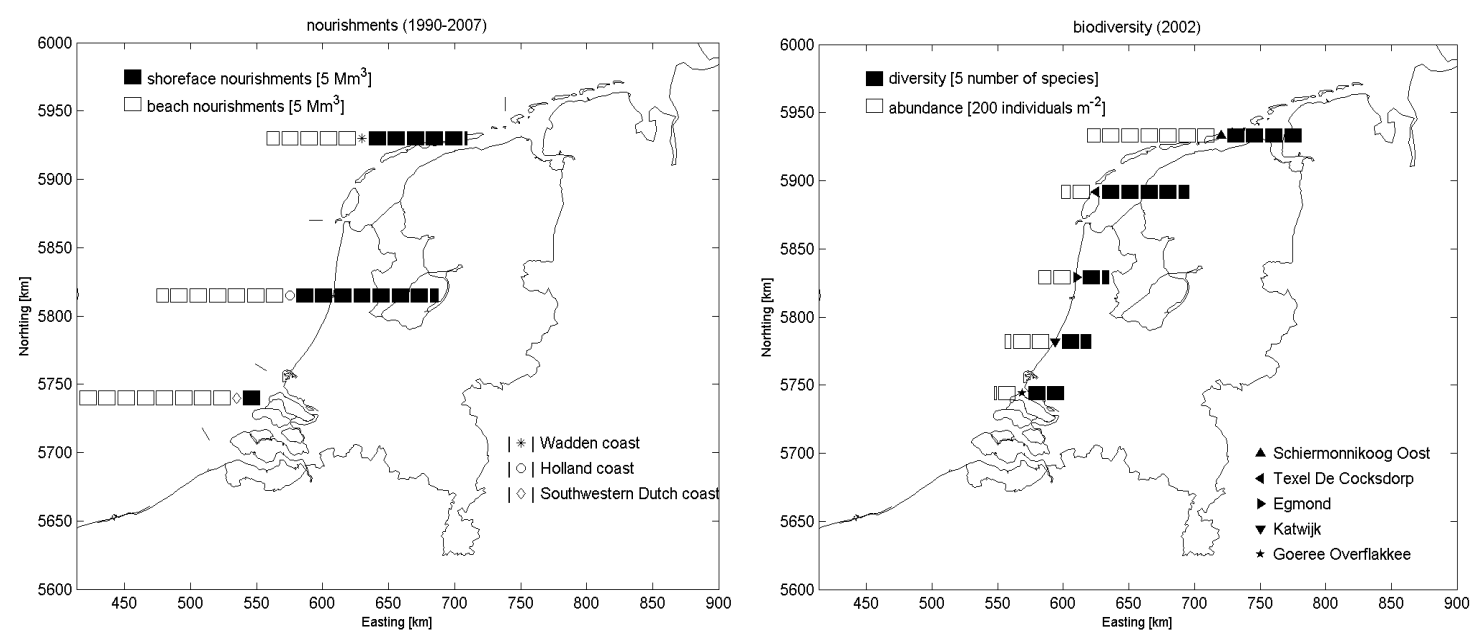

Figure 1. Overview of nourishments executed along the Dutch coast $(1990-2007)$ and the biodiversity and abundance at five different locations (2002).

The interaction between benthos and nourishments is two-sided. First, the impact of nourishments on benthos is only significant on the short-term: for most species, abundance and biomass will largely recover ca. 1 year after completion of the nourishment. Full recovery of the benthic community is considered to take 2-5 years (Baptist et al., 2009). However, impact of benthos on nourishments has never been quantified. Some benthic species are known to optimize their own environment, known as bio-engineers (Widdows and Brinsley, 2002). Bio-engineers can roughly be divided in stabilizers and destabilisers. Diatoms are an example of stabilizers, which glue the sediment together and increase the critical shear stress for erosion (Riethmüller et al., 2000). 
Crawling of organisms trough the sediment causes an increase in porosity and consequently destabilize the sediment which can easily be eroded (Austen et al., 1999). Extremely high densities of tube building worms (Lanice conchilega) were found during a field measurement between the two breaker banks near Egmond aan Zee (Janssen and Mulder, 2005 and Van Dalfsen, 2006). Moreover, Van Dalfsen and Essink (1997) and Van Dalfsen (2006) also detected the patchy distribution of tube building worms in the foreshore at the Wadden Sea islands Terschelling, Ameland, Schiermonnikoog and Nordeney, with densities up to thousands of tube building worms per $\mathrm{m}^{2}$ locally in between the two breaker banks. However, at most stations tube building worms were absent. Tube building worms can both act as stabilizers and destabilisers. For very small densities scour is induced by the tubes locally, while for dense patches, the water is deflected around and over the patch and the sediment within the patch is stabilized (Eckman et al., 1981). The tube building worms partly protrude from the sediment $(\sim 3.5 \mathrm{~cm})$ and have a diameter of around $0.5 \mathrm{~cm}$. The relative coverage area (ratio of tube building worms patches over the total area in which the occur) is around $20 \%$ with patch areas up to tens of square meters (Rabaut et al., 2008). Moreover, the shear strength within the patches increases for increasing densities, showing the compaction of the sediment by the bio-engineering capacity of the tube building worms. Given the densities found in the field measurements (thousands of individuals per $\mathrm{m}^{2}$ ), it is hypothesized that small-scale tube building worms stabilize the sediment and thereby the large-scale stability of the coastal profile (Murray et al., 2002).

\section{MODEL SET-UP}

\section{Biota-sediment-fluid interaction}

To model the influence of tube building worms on the near bottom flow, we represent the tube building worm by thin piles on the bottom of the seabed. In this way, we are able to include the worms in a vegetation model (Uittenbogaard, 2003). This vegetation model is able to calculate the turbulent flow over and through vegetation (thin piles) in water of limited depth. The vegetation model explicitly accounts for the influence of cylindrical structures on drag and turbulence by an extra source term of friction force in the momentum equation and an extra source term of Total Kinetic Energy (TKE) and turbulent energy dissipation in the $k-\varepsilon$ equations respectively. The vegetation model is included in Delft3D-FLOW model, which is a three-dimensional hydrodynamic model (Lesser et al., 2004). The Delft3D-FLOW model computes flow characteristics (flow velocity, turbulence) dynamically in time over a three-dimensional spatial grid. For a detailed mathematical description of the vegetation model see Bouma et al. (2007).
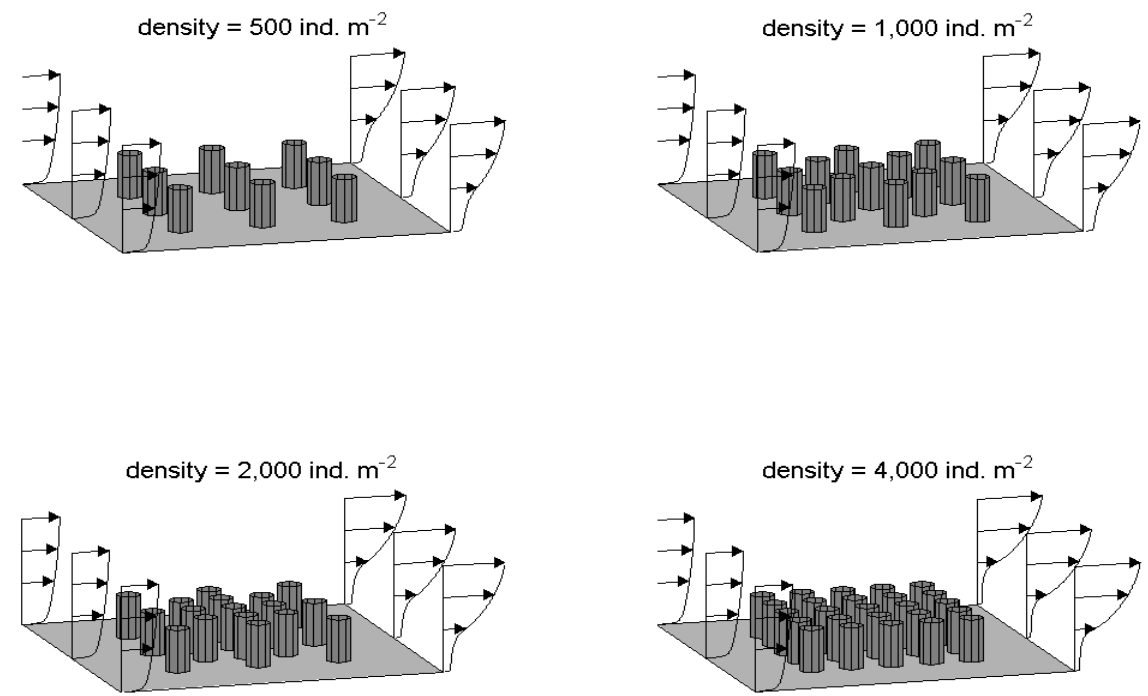

Figure 2. Schematic overview of the model set-up to determine the reduction of the flow velocity by tube building worms. Flow velocity profiles correspond to the indicated densities (individuals $\mathrm{m}^{-2}$ ). Copy from Borsje et al. (2009b). 


\section{Nourishments}

In this paper we focus on the Egmond coast (The Netherlands), as it has been relatively well described with respect to physical parameters, underwater nourishments and density tube building worms (Figure 1). In the Delft3D application, The FLOW-grid covers an area of 1500 (cross-shore) and 5400 (longshore) meters, with a constant grid size (40 meters) in longshore direction and a decreasing grid size in cross-shore direction (decreasing from 40 meters to 20 meters near the shore). The model has 12 vertical layers, which are very thin near the bed and near the top of the watercollumn, and thicker in mid-water. The WAVE-grid covers an area of 1650 (cross-shore) and 11250 (longshore) meters, with a constant grid size of $50 \times 50 \mathrm{~m}$, to ensure a realistic wave condition at the lateral FLOW grid boundaries (Figure 2). The roller model is used to generate wave forcing and the $k-\varepsilon$ turbulence closure is used to include the effects of waves and tube building worms on turbulence levels. For details on the model set-up, the interested reader is referred to Van der Werf et al. (2009).
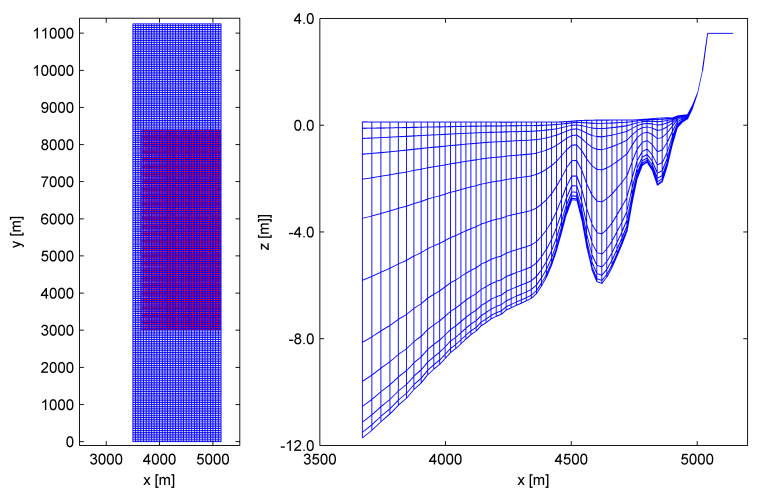

Figure 3. Plan view of FLOW (red) and WAVE (blue) grids (left) and side view of FLOW grid (right).

Two different initial bathymetries are used (Figure 4). One is a long-shore uniform coastline with two breaker bars and an intertidal swash bar. The other is nourished with $800,000 \mathrm{~m}^{3}$ sand in the trough between the breaker bars over a length of $2 \mathrm{~km}$ (characteristic nourishment for the Dutch coast). The model is forced by a single semi-diurnal tidal cycle (with a duration of 12.5 hours) and with four typical wave conditions representative for the long-term morphological development. Measured biomass of tube building worms is maximum in the trough between the two breaker bars, reducing to almost zero shoreward and on top of the breaker bar. For both bathymetries, three scenarios are modeled in which the maximum density tube building worms is varied $(0,5,000$ and 10,000 ind. $\mathrm{m}^{-2}$ ).
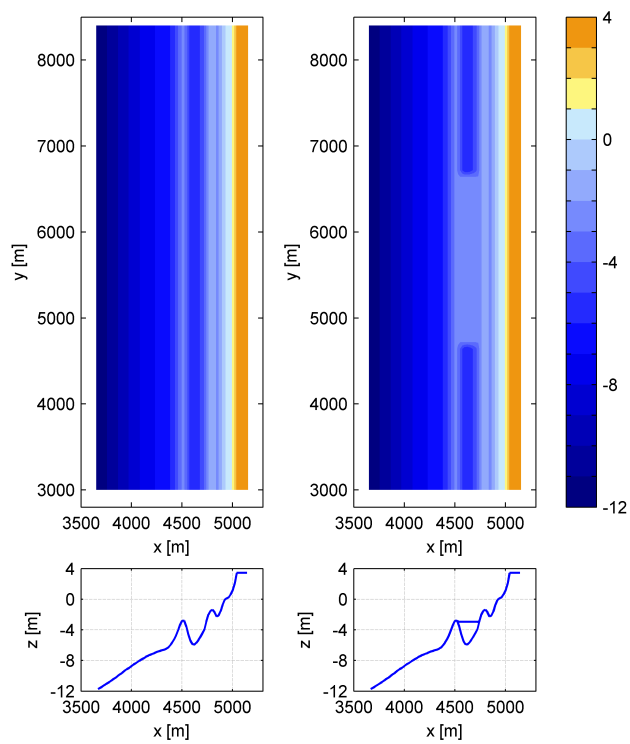

Figure 4. Bathymetry of the Egmond model $(\mathrm{m})$. Left the situation without a nourishment, showing two breaker bars in the surf zone and one swash bar. Right the situation with a nourishment of $400 \mathrm{~m}^{3} \mathrm{~m}^{-1}$ over $2 \mathrm{~km}$. 


\section{RESULTS}

\section{Hydrodynamics}

To validate the tube building worm module, flume experiments are used in which the maximum flow deceleration $1.5 \mathrm{~cm}$ above the bed within the patch was measured for varying densities of artificial tubes with comparable dimensions (height and diameter) as tube building worms (Friedrichs et al., 2000). Flow deceleration is expressed as the percentage of the flow velocity relative to the reference flow velocity at the beginning of the patch (Figure 2).

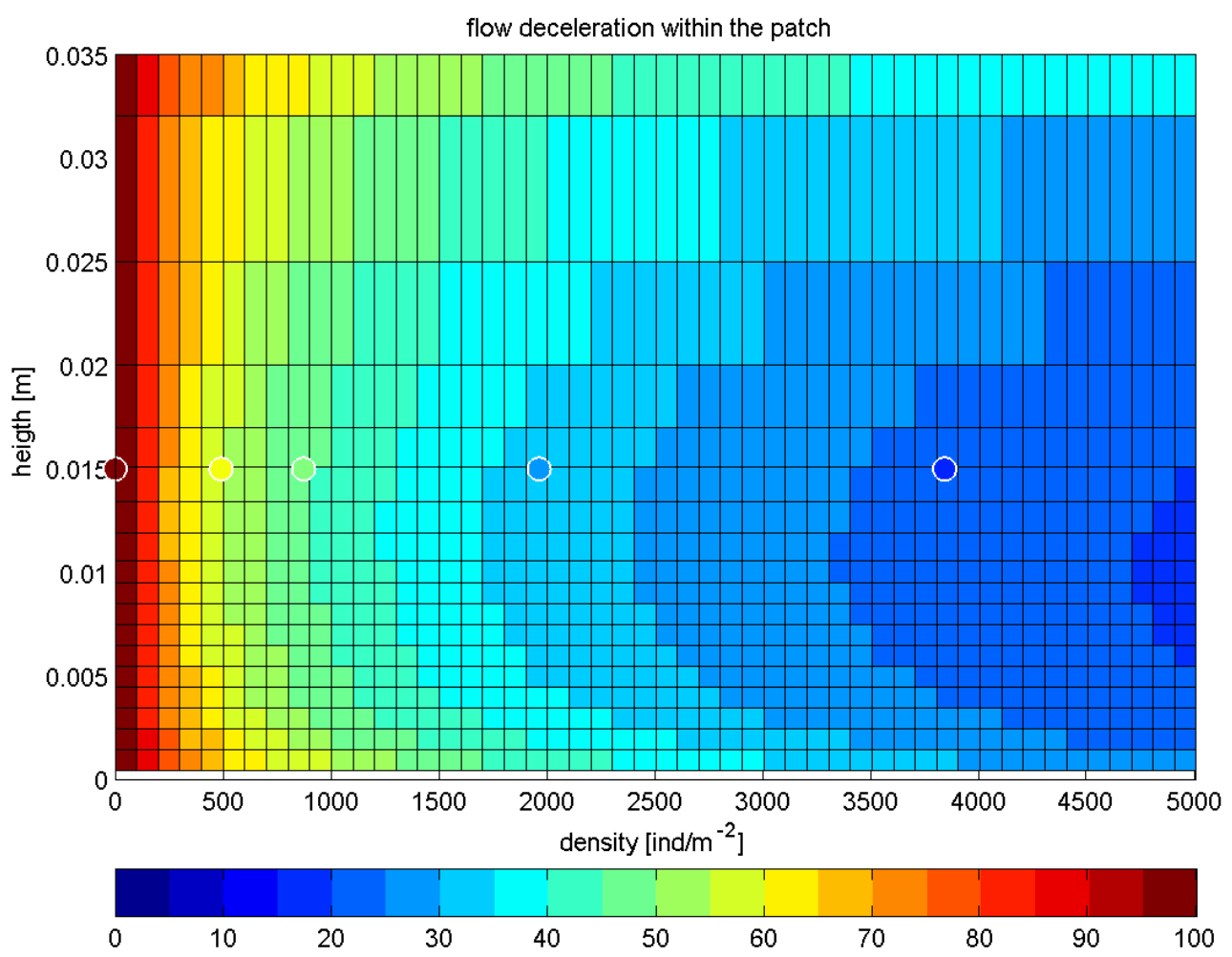

Figure 5. Validation of the tube building worm module. Flow deceleration for increasing densities of tube building worms at different heights above the bed. Filled circles show flume experiments (Friedrichs et al., 2000), shaded areas are model results.

Flow deceleration predicted by the model (Figure 5: shaded area) is in good agreement with flume measurements (Figure 5: filled circles). The gradient in flow deceleration is largest for small densities, whereas for large densities the flow deceleration reaches a constant value of around $20 \%$ of the reference velocity. The flow deceleration is not uniform over the height; between 1 and $1.5 \mathrm{~cm}$ above the bed the flow deceleration is maximum.

The interaction between the patch and the environment shows clearly both a stabilizing and a destabilizing effect (Figure 6A). First the flow within the patch is reduced as already shown before (Figure 5). However, the flow on top of the patch is accelerated by the presence of the patch resulting in an uplift of water closely in front of the patch. This, in turn, causes an acceleration of horizontal flow just in front of the uplifting water. The result is an increase in bed shear stress in front of the patch with $20 \%$ and a reduction of the bed shear stress of $85 \%$ within the patch. Moreover, in the wake zone of the patch the bed shear stress is also reduced over a distance of approximately one patch length. The flow is mostly deflected over the patch (Figure 6B), and partly around the patch (Figure $6 \mathrm{C})$. Note the amplification factors used for visualization. In the simulations the maximum value of vertical velocity $w$ is ten times larger than that of horizontal (cross-patch) velocity $v$. 
(A)
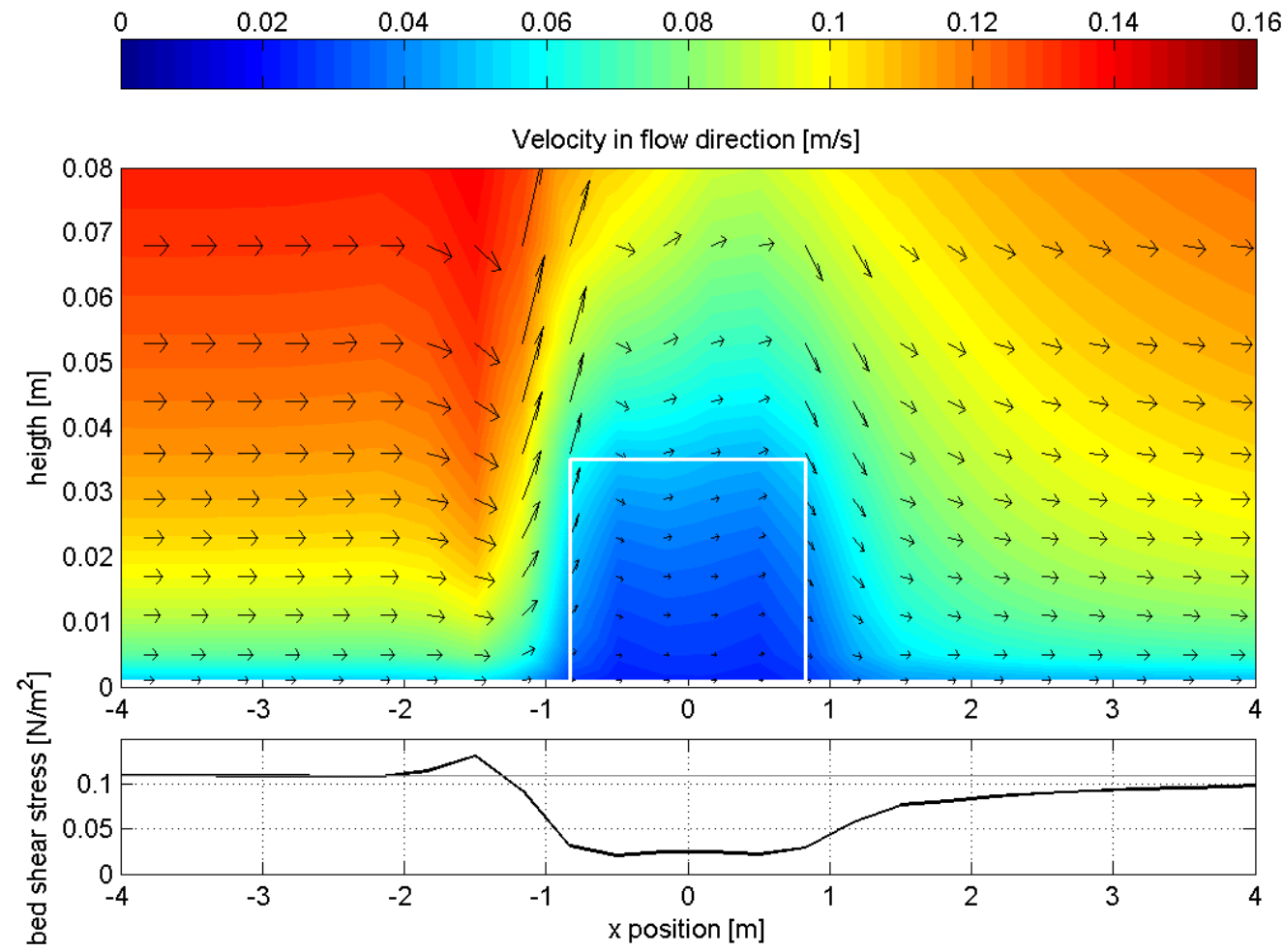

(B)
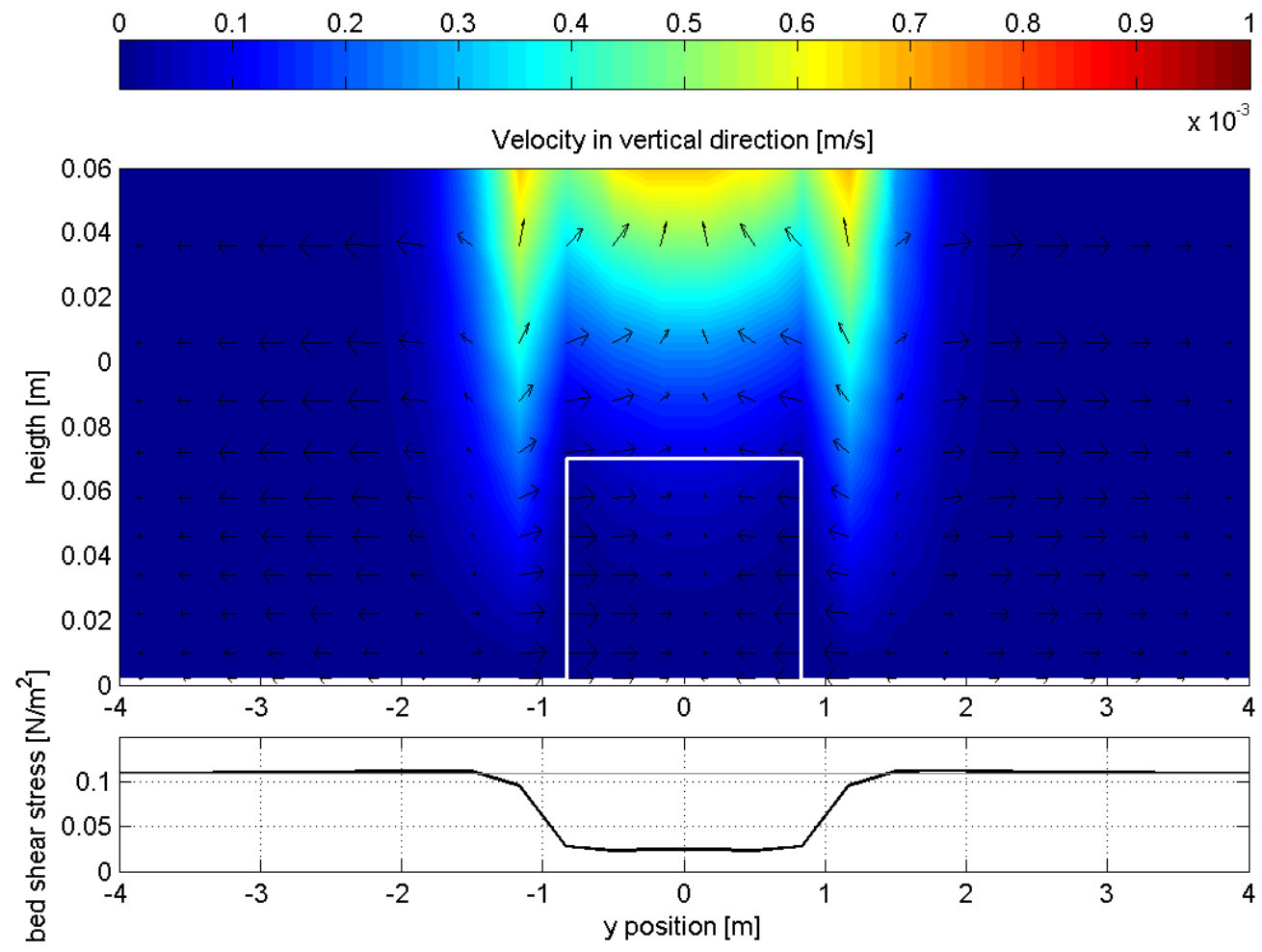
(C)

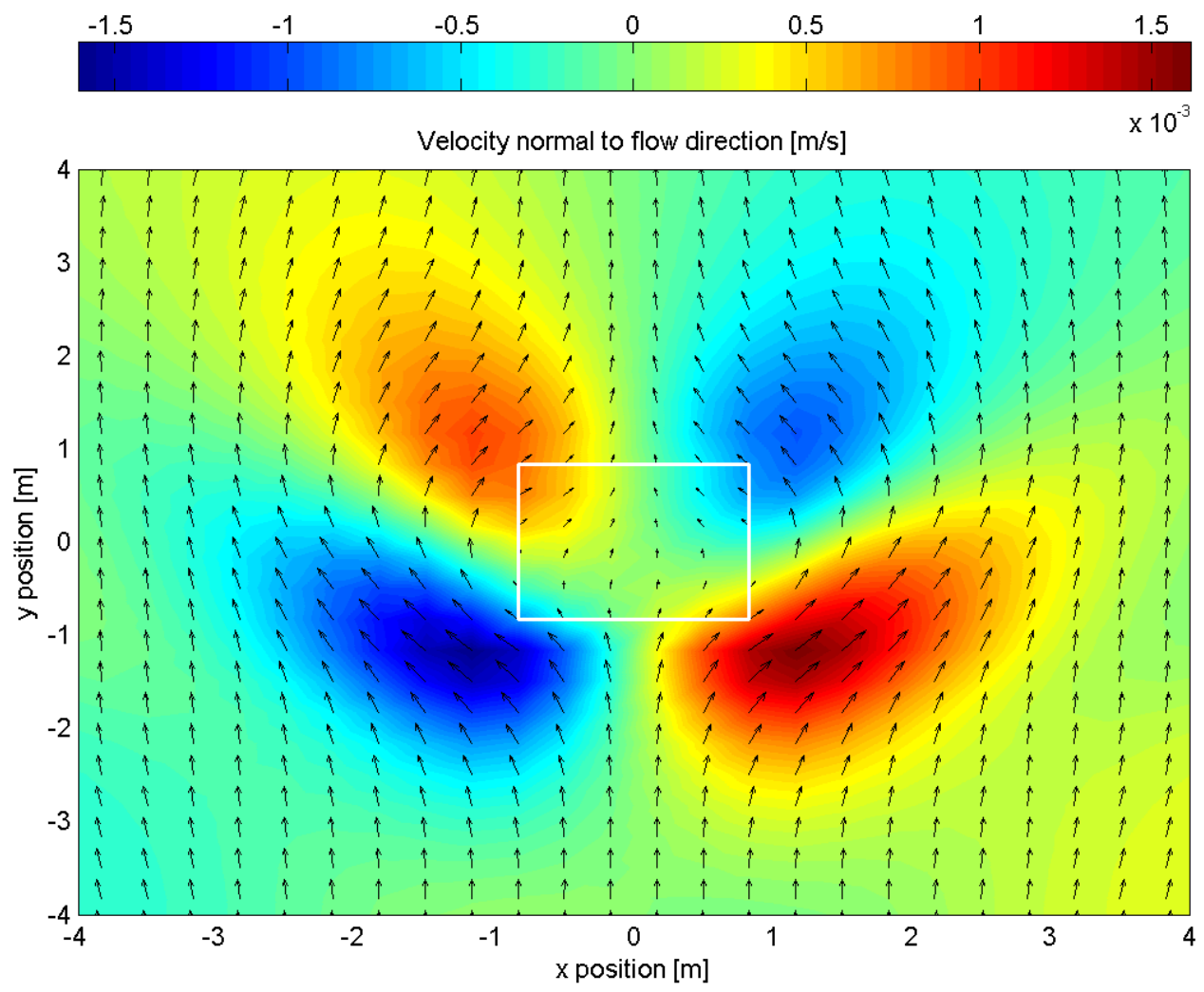

Figure 6. Interaction between a tube building worm patch and the environment, for a patch size of $1.6 \mathrm{~m} \times 1.6 \mathrm{~m}$, free stream flow velocity of $0.2 \mathrm{~m} \mathrm{~s}^{-1}$, waterdepth of $2 \mathrm{~m}$ and a density of 2000 ind. $\mathrm{m}^{-2}$. (A) Flow velocity $(u)$ in flow direction. Arrows indicate the vector $(u, w)$ strength and angle (vertical velocity component $w$ is multiplied by a factor 10 for visualization purposes). Patch indicated with white lines. Bed shear stress indicated in the lower panel. (B) Flow velocity $(w)$ in vertical direction. Arrows indicate the vector $(v, w)$ strength and angle (flow velocity component $v$ is multiplied by a factor 5 ). Bed shear stress indicated in lower panel. (C) Flow velocity (v) normal to flow direction. Arrows indicate the vector $(u, v)$ strength and angle (velocity component $v$ is multiplied by a factor 50 ). 


\section{Morphological development}

The morphological development of the bed profile without nourishment and without tube building worms shows a migration of the outer bar of $150 \mathrm{~m}$ seaward after a 1 year period. Moreover, the trough between the two breaker banks becomes shallower (Figure 7A, blue line). The coastline is still uniform after one year. The model is capable to reproduce the overall erosive and depositional trends measured in the field and the complex cross-shore dynamics of the surfer zone, as discussed in detail by Giardino et al. (2010). However, the simulated bar erosion is excessive compared to field measurements. By including tube building worms in the model, the outer bar seems to be stabilized (Figure 7A, dark green and light green line), and the migration of the outer bar is only $100 \mathrm{~m}$ seaward. Moreover, the through between the two breaker banks is filled up more, compared to the default run with no tube building worms included. A maximum tube building worm density of 10,000 ind. $\mathrm{m}^{-2}$ stabilizes the outer bar slightly more, compared to a maximum tube building worm density of 5,000 ind. $\mathrm{m}^{-2}$, but there is no large difference in bed level between the two densities. This observation can be explained by the maximum decrease in flow velocity within the patch for densities larger than 5,000 ind. $\mathrm{m}^{-2}$ (Figure 5), but the still increasing bed shear stress in front of the patch for increasing densities (Figure 6A).
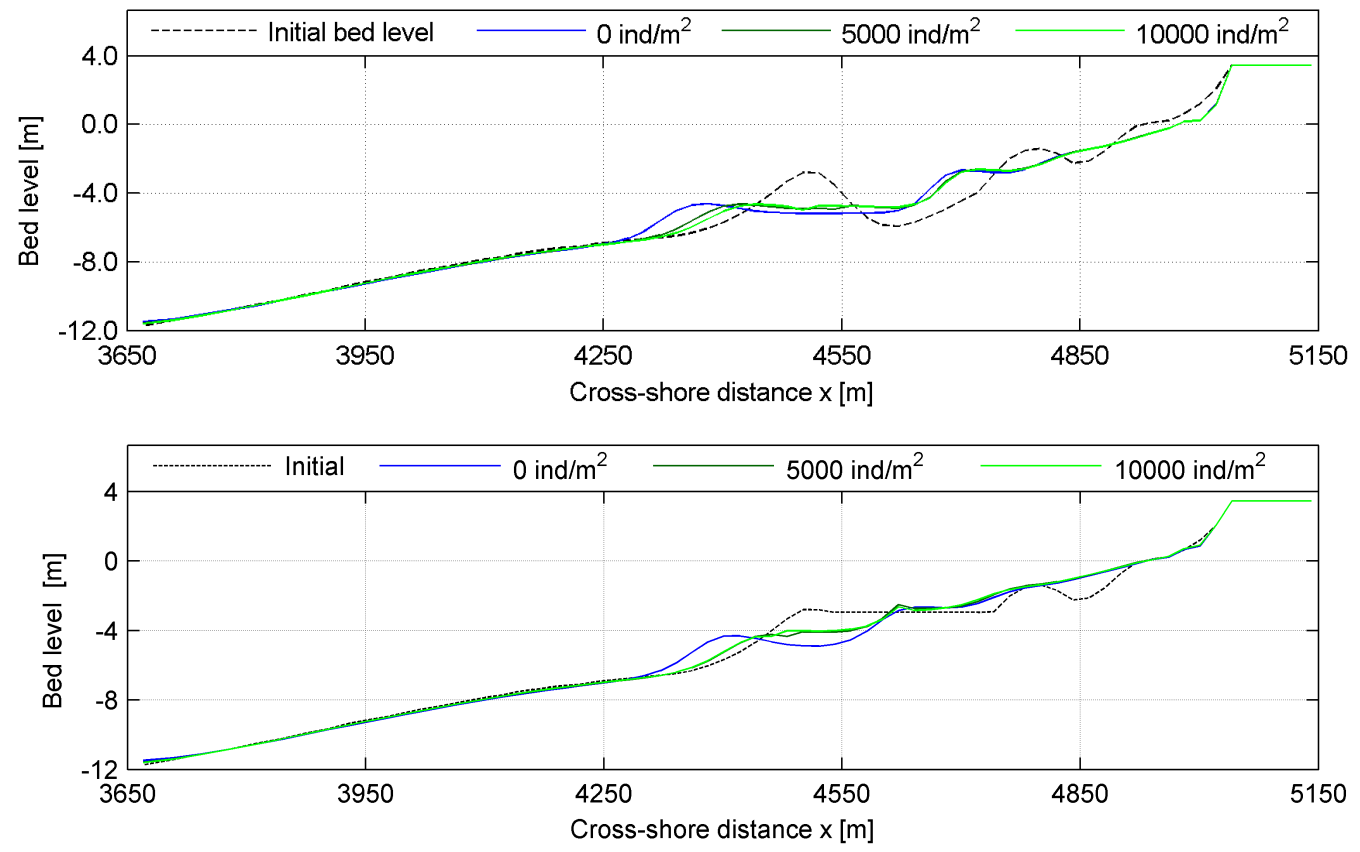

Figure 7. Bed levels in center transect after 1 year for a situation without nourishment (top; A) and with nourishment (under; B). Indicated densities tube building worms are maximum densities measured in the troughs of the breaker banks, reducing to almost zero shoreward and on top of the breaker bar.

By including a nourishment in the model (Figure 4), the morphological development after one year without tube building worms shows an accretion of sand shoreward (Figure 7B, blue line), and a diffusion of sand along the coast due to the so-called lee and feeder effects, as discussed in detail by Van der Werf et al. (2010). However, the total volume of sand remains constant in the model throughout the year. Tube building worms hinder diffusion of the sediment, resulting in more sand in the nourished area after a 1 year period. Moreover, the migration of the outer bar is delayed by $50 \mathrm{~m}$, compared to case in which no tube building worms are present (Figure 7B, light green and dark green line). Again, the difference between different maximum densities is minor.

The decrease in bar migration and increase in sediment volume within the tube building worm field is explained by the decrease in both longshore and offshore sediment transport. During a storm, the decrease in sediment transport is maximum, with a decrease in longshore sediment transport by $50 \%$ and a decrease in offshore sediment transport by $40 \%$, compared to the default case with no tube building worms. Field experiments also demonstrated the stabilization of sediment by tube building worms (Rabaut et al., 2008). Tube building worms both increase the shear strength of the sediment inside the patch and the elevation of the tube building worm patch compared to the surrounding area. 


\section{DISCUSSION}

This paper explores the biogeomorphological interactions in the foreshore in general, with a focus on the two-sided effect between benthos and underwater nourishments. Tube building worms are focused upon in this study as representative stabilizers of the sediment, however much more organisms are known to impact the sediment dynamics in the foreshore. The razor clam Ensis americanus is for example known to live in high densities in the deeper water in the foreshore (around $6 \mathrm{~m}$ waterdepth) (Baptist et al., 2009). The razor clam is a suspension feeder, however able to withdraw into the sediment when physical disturbance is present (Muir, 2003). The exact impact on the sediment dynamics is not known and therefore not included in this study. However, given the high abundance of the razor clam it is recommended to study the biogeomorphological interactions for this species.

Underwater nourishment negatively affects benthic life. Therefore, it will take some time before the nourishment is influenced by bio-engineers. By including different return periods of tube building worms in the model, the effect on the morphological development is investigated. A return period of up to 3 months hardly influenced the morphological development on the large scale. However, the model results show the development of a sand ridge locally with a height of $50 \mathrm{~cm}$ at the location of their maximum density when the tube building worms return directly after the nourishment. For longer return periods, this sand ridge becomes less high.

Another nourishment option, is to put the sand against the outer breaker bank. This option is from an ecological perspective interesting, while the tube building worms, which are not present at this location, are not destroyed by the nourishment. It is recommended to investigate the biogeomorphological interactions for this nourishment option in a follow-up study.

Only the tube building worm module is validated against field and flume data, the results of the model including the nourishment and the tube building worms showed qualitative agreement between field measurements (less excessive erosion of the outer breaker bank compared to the default run). Tube building worms occur in patches of several square meters (Rabaut et al., 2008). Consequently, the flow is deflected around the patches causing a local acceleration of the flow and erosion between the patches. The exact size of the patches as well as the distance between the patches are not known. They are of special interest to validate the model quantitatively. Possible ways to monitor the patch size of tube building worms in the surf zone is to define a series of transects in the troughs between the two breaker banks, perpendicular to the transects of the coastal profile, or to use a high resolution camera, which is able to detect the occurrence and the patch size of the tube building assemblage (Degraer et al., 2008).

\section{CONCLUSIONS}

Different field studies indicate the occurrence of tube building worms in between the breaker bars in the foreshore. These tube building worms protrude several centimeters from the sediment and lives in dense patches (up to 10,000 ind. $\mathrm{m}^{-2}$ ). Given their presence, a large impact on hydrodynamics and sediment dynamics is observed, both in flume studies and field experiments. The proposed model is validated with these flume and field studies and show a decrease of bed shear stress within the patch, up to $85 \%$ compared to the default case. For high densities of tube building worms, skimming flow occurs, which is a situation in which most of the water is deflected around and over the patches. Moreover, tube building worms are able to influence the large scale morphology of the coastal profile for the case without nourishment. The migration of the outer breaker bar is only $100 \mathrm{~m}$ per year, compared to $150 \mathrm{~m}$ per year for the default run. By including a nourishment in the model, tube building worms are able to stabilize a nourishment by keeping the sand in the original position, and in this way increase the lifetime of the nourishment. The results show the potential importance of incorporating biological activity in a process-based model, in order to support decision making regarding nourishments and conservations of coastal systems with large biological activity.

\section{ACKNOWLEDGEMENTS}

This research is supported by the Dutch Technology Foundation STW, applied science division of NWO and the Technology Program of the Dutch Ministry of Economic Affairs. Deltares funded part of the research (project Kustlijnzorg) and made its Delft3D software available. 


\section{REFERENCES}

Austen, I., Andersen, T.J., Edelvang, K., 1999. The influence of benthic diatoms and invertebrates on the erodibility of an intertidal mudflat, the Danish Wadden Sea. Estuarine, Coastal and Shelf Science 49, 99-111.

Baptist, M.J., Tamis, J.E., Borsje, B.W., van der Werf, J.J., 2009. Review of the geomorphological, benthic ecological and biogeomorphological effects of nourishments on the shoreface and surf zone of the Dutch coast. IMARES Report C113/08, Deltares Report Z4582.50.

Borsje, B.W., De Vries, M.B., Bouma, T.J., Besio, G., Hulscher, S.J.M.H., Herman, P.M.J,. 2009 a. Modelling bio-geomorphological influences for offshore sandwaves. Continental Shelf Research 29, 1289-1301.

Borsje, B.W., Hulscher, S.J.M.H., Herman, P.M.J., de Vries, M.B., 2009b. On the parameterization of biological influences on offshore sand wave dynamics. Ocean Dynamics 59, 659-670.

Bouma, T.J., van Duren, L.A., Temmerman, S., Claverie, T., Blanco-Garcia, A., Ysebaert, T., Herman, P.M.J., 2007. Spatial flow and sedimentation patterns within patch of epibenthic structures: combining field, flume and modeling experiments. Continental Shelf Research 27, 1020-1045.

De Ronde, J.G., Mulder, J.P.M., Spanhoff, R., 2003. Morphological developments and coastal zone management in the Netherlands. International conference on Estuaries and Coasts. Hangzhou, China, 46-56.

Degraer S., Verfaillie, E., Willems W., Adriaens, E., Vincx, M., Van Lancker, V., 2008. Habitat suitability modeling as a mapping tool for macro-benthic communities: an example from the Belgian part of the North Sea. Continental Shelf Research 28, 369-379.

Eckman, J.E., Nowell, A.R.M., Jumars, P.A., 1981. Sediment destabilization by animal tubes. Journal of Marine Research 39,361-374.

Friedrichs, M., Graf, G., Spring, B., 2000. Skimming flow induced over a simulated polychaete tube lawn at low population densities. Marine Ecology Progress Series 192, 219-228.

Giardino, A., van der Werf, J., van Ormondt, M., Brière, C., Walstra, D.J., 2010. Detailed morphodynamic simulations of shoreface nourishment scenarios. In: Vionnet, C.A., Garcia, M.H., Latrubesse, E.M., Perillo, G.M.E. (Eds). Proceedings of the sixth IAHR Symposium on River, Coastal and Estuarine Morphodynamics (RCEM), Santa Fe, Argentina, pp 947-952.

Grunnet, N.M., Walstra, D.R., Ruessink, B.G., 2004. Process-based modeling of a shoreface nourishment. Coastal Engineering 51, 581-607.

Grunnet, N.M., Ruessink, B.G., 2005. Morphodynamic response of nearshore bars to a shoreface nourishment. Coastal Engineering 52, 119-137.

Hamm, L., Capobianco, M., Detee, H.H., Lechuga, A., Spanhoff, R., Stive, M.J.F., 2002. A summary of European experience with shore nourishment. Coastal Engineering 47, 237-264.

Hanson, H., Brampton, A., Capobianco, M., Dette, H.H., Hamm, L., Laustrup, C., Lechuga, A., Spanhoff, R., 2002. Beach nourishment projects, practices, and objectives - a European overview. Coastal Engineering 47, 81-111.

Janssen, G., Mulder, S., 2005, Zonation of macrofauna across sandy beaches and surf zones along the Dutch coast. Oceanologia 47, 265-282.

Lesser, G., Roelvink, J., van Kester, J., Stelling, G., 2004. Development and validation of a threedimensional morphological model. Coastal Engineering 51, 883-915.

Muir, S. D., 2003. The biology of razor clams (Ensis spp.) and their emergent fishery on the West coast of Scotland. University Marine Biological Station. Millport, University of London: 1 - 280.

Murray, J.M.H., Meadows, A., Meadows, P.S., 2002. Biogeomorphological implications of microscale interactions between sediment geotechnics and marine benthos: a review. Geomorphologiy 47, 15-30.

Ojeda, E., Ruessink, B.G., Guillen, J., 2008. Morphodynamic response of two-barred beach to a shoreface nourishment. Coastal Engineering 55, 1185-1196.

Rabaut, M., Guilini, K., Van Hoey, G., Vincx, M., Degraer, S., 2007. A bio-engineered soft-bottom environment: The impact of Lanice conchilega on the benthic species-specific densities and community structure. Estuarine, Coastal and Shelf Science 75, 525-536.

Rabaut, M., Vincs, M., Degraer, S., 2008. Do Lanice conchilega (sandmason) aggregations classify as reefs? Quantifying habitat modifying effects. Helgoland Marine Research, 1-10. 
Renschler, C.S., Doyle, M.W., Thoms, M., 2007. Geomorphology and ecosystems: Challenges and keys for success in bridging disciplines. Geomorphology 89, 1-8.

Riethmüller, R., Heineke, M., Kühl, H., Keuker-Rüdiger, R., 2000. Chlorophyll $a$ concentration as an index of sediment surface stabilization by microphytobenthos? Continental Shelf Research 20, 1351-1372.

Uittenbogaard, R., 2003. Modelling turbulence in vegetated aquatic flows. In international workshop on riparian forest vegetated channels: hydraulic, morphological and ecological aspects, 20-22 February 2003, Trento, Italy, 2003.

Van Dalfsen, J.A., Essink, K., 1997. Risk analysis of coastal nourishment techniques (RIACON). Rijksinstituut voor Kust en Zee/RIKZ. Report RIKZ-97.022.

Van Dalfsen, J.A., 2006 Inventarisatie brandingszone zandige kust. TNO-rapport B\&O-DHR2005/251.

Van der Werf, J.J., Giardino, A., van Ormondt, M., Walstra, D.J., Ramaekers, G., 2010. Detailed morphodynamic simulations of shoreface nourishment scenarios. In: Vionnet, C.A., Garcia, M.H., Latrubesse, E.M., Perillo, G.M.E. (Eds). Proceedings of the sixth IAHR Symposium on River, Coastal and Estuarine Morphodynamics (RCEM), Santa Fe, Argentina, pp 953-957.

Van Duin, M.J.P., Wiersma, N.R., Walstra, D.J.R., Van Rijn, L.C., Stive, M.J.F., 2004. Nourishing the shoreface: observations and hindcasting of the Egmond case, The Netherlands. Coastal Engineering 51, 813-837.

Van Leeuwen, S., Dodd, N., Calvete, D., Falques, A., 2007. Linear evolution of a shoreface nourishment. Coastal Engineering 54, 417-431.

Widdows, J., Brinsley, M.D., 2002. Impact of biotic and abiotic processes on sediment dynamics and the consequences to the structure and functioning of the intertidal zone. Journal of Sea Research $48,143-156$. 